第 6 圖（A）第五コークス爐乾燥温度上昇曲腺

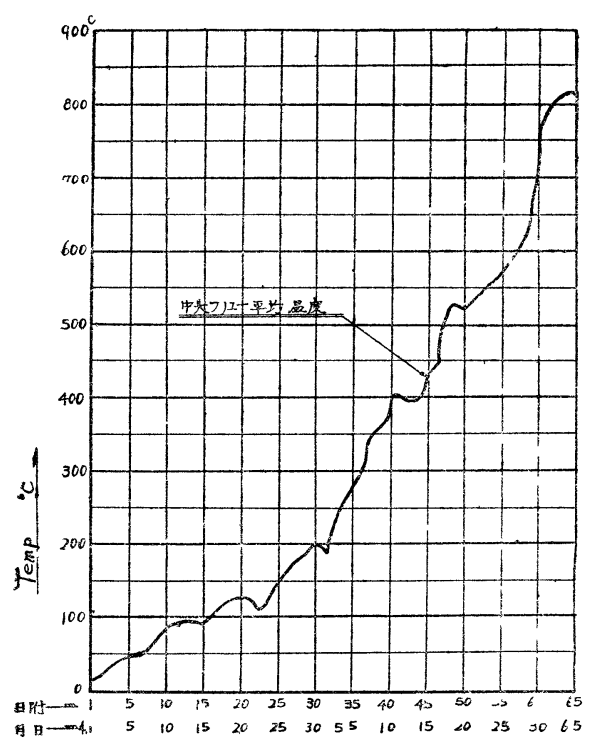

第 6 圆（B） 第六コークス爐乾燥温度上昇曲線

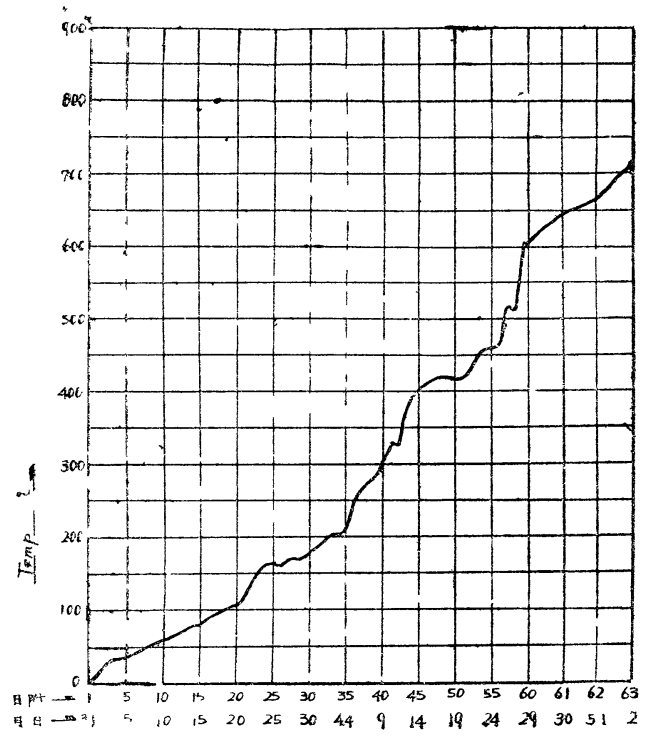

\title{
高爐コークス用石炭價值指數に就て
}

一一昭加 24 年 3 月 28 日受理一

日鐵穬業株式會社 北松穬業所酒手

\section{[I] 製鐵用原料炭の使用効率}

北松强粘結炭に對する品位查定法は未た確定的なる のが公表されていない情である。北松炭の價値はとの 邊にあるかを檢討寸るため，次の如く高盧コークス用 石炭即ち製鐵用原料炭について考之てみた。

製鐵所に於て高盧用コークスを造る石炭の使用效率 は量的效率たる可洗率(矫分と步留) と質的効率たる使 用壯態に於ける石炭の粘結性 (單味コークスの强度, 配合の場合の抱合力二配合强度）を中心として查定す へきたと考兄られている。

他の要素としては受入粗炭の粒度, 硫黄分、コーク スの反應性等があるコークスの反應性は製鐵方面に於 てもまた數値的な結論炪ていないから，一應これに は觸れぬことにした。

\section{[II]量的効率}

消費地ては無洗下使い，洗炭は生產地たけてやるこ とは，輸迩その他の關係から理想的てあるか，大量使
用の製鐵新ては多數の異つた銘柄つものか入荷するの て，コークス灰分を一定にする立前からは種々困難か： 生して來る。

努い、製鐵所ては大荷炭の大部分を洗炭することにな る。そして何種類かの石孷を配合して使 万。現在，山 元冼笑の䅔齊呫々製鐵所使用灰分の一致しないのか實 壯てある。又高炎分の原炭の水珗は 1 回洗炭上り 2 回 洗炭によつて低灰分にした方か回收率か高いものも出 る。

一應現壯に從つて可烍性を主體にしな灰分指數を以 て量的効率の尺度とした。灰分指數なる名䊈は步留指 數或は可洗性數と言つても差支之はない。

製驖所ては單味使用よりも配合使用の方か多いが， 一定灰分の裝入炭を告るためには，各炭を各裝入灰分 まて水洗してもよいし，又低灰分の石炭がれはこれ 々抱合せる石炭の灰分は高い壯態て使えるからその水 洗步留は高くてよいし，高灰分の石炭に抱合せる石炭 
の灰分は低下させねばならぬから水洗步留は下つて來 る。從つて灰分は步留といら量的なるのに換算され る。勿論全部夌無洗で使ら場合も各種灰分の石炭は, 一定の標隼灰分か決れは各々の灰分圧に從つて步留に 換算加出來る。

今ュークス灰分を 18\% にして装入炭灰分 13\% 標隼にする。この一定のコークス灰分に對する石荻の 灰分は，揮發分の多い、弱粘結炭は低く揮發分の少い强 粘結咴は高くなるのてあるか，ガス發生量のことる考 えて，一應區別せすに平均 13\%とした。

灰分指數は次の條件の許に總步留を出してその值を 指數とした。

\section{（1）洗炭步留}

標隼乍分 $13 \%$ のときの實際洗炭步留を灰分指數の 主體にして後速の (2)，(3)の禣正する。 洗炭步留は次式加計算て出す。

可洗曲線から求めた裝入時灰分の步留一 $\mathrm{A}$

\section{=實際洗炭步留}

A $: 3 \%$ 可洗曲線步留 $90 \%$ 上上

$$
\begin{array}{lll}
5 \% & \quad & 70 \sim 89 \% \\
7 \% & \quad 69 \sim \text { 以下 }
\end{array}
$$

\section{（2）灰分補正量}

標隼灰分 $13 \%$ 以下の石炭と, 經濟的可洗度から標 隼灰分以上に止める石炭とは，その灰分に相當する步 留を禣正する。

$$
\text { 灰分差 1\%につき } 35 \% \text { 步留補正 }
$$

35\% としたのは 2\% は洗炭步留差て15\%は洗炭費 と考えたのて，賞罰の意味から少し大きい値にした。

\section{(3) 二號炭補正量}

灰分 35\% の二號炭を回收することとし，その回收 率の $1 / 3$ を禣正量とする。1/3 としたのは價格至と再 洗費を考慮したものでる。回收率は可洗曲線に於て 精炭の步留線が示性曲線と交る點を起䗉とした二次可 洗曲線の步留を以て示すこととする。

(4) 總步留

以上を表示すると第 1 表の樣になる。表中 8 欄の標 凖灰分 $13 \%$ 換算總步留を以て最後に禣正された灰分 指數とする。

\section{第}

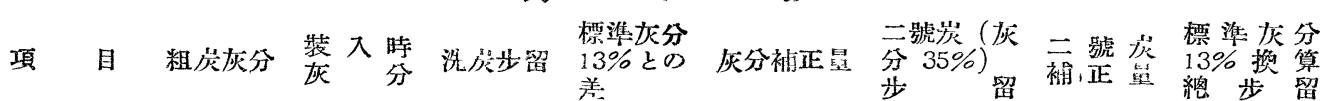
番 號 (1) (2) (3) (4) (5)

算出式 - - - (2) - - -

\section{[11]質的效率}

製鐵所に新銘柄岩や久し振りに入荷したるの，或は

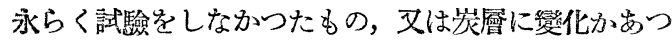
たり，その他疑問か起つたすのは入荷原粠岑に就て綜 合的な試驗をする。先つ大荷したま〉の粗参の單味罐 燒試驗をやり，次に各段階の灰分に手冼いしたものの 單味維珪武驗をやる。その結果によつて强粘結炭てあ れは弱粘結炭と, 弱粘結炭てあれは, 强粘結岑と夫々

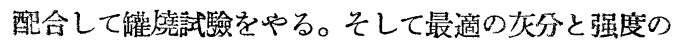
䁫を見出す。命大事をとるときは本嘿燒試驗をする， $\frac{(4) \times 35}{100}$

(6)

(7)

$-\frac{6 \times 1 / 3}{100}$
(8)

(3) $\pm(5)+(7)$

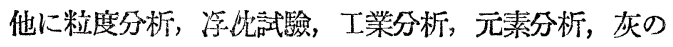
組成分析をこれと併行的にやるか、コークス爐の作業 指检の主體は䌯堯”式驗から出を潰裂强度に置いてむ る。

石炭の粘結度郎ちュークスの强度は石炭の膨脹率や 元素分析からの $\mathrm{H} / \mathrm{O}$ 值に大いに關係かあるか，比例 しない蛅子あるのて，これらては表わし切れない。䚭 燒試铪ては第2表の柡に本空燒と大差かないのて，現 在てはこれに據るのか一番實際的である。

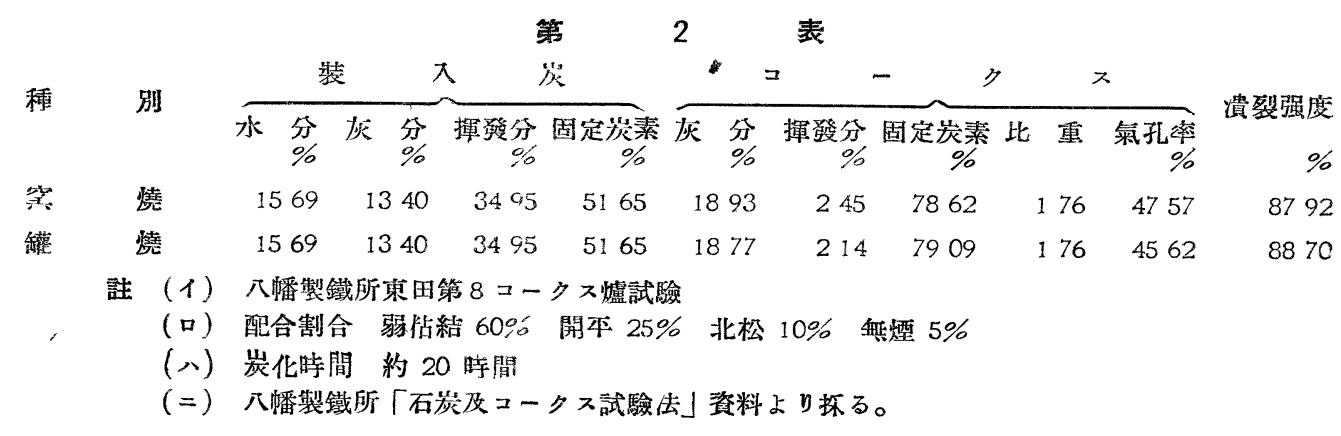


(A) 罐燒試驗法 罐燒試驗法と言うのは石油空罐 に入れた石炭武料をコークス㠠に裝入して出來たコー クスを試驗する方法てある。

今試羷方法の條件を次の榬に定める。

（1）罐燒試驗法は八幡製鐵所法に據る。

（2）試料の粒度は次の如く調整する。 $6 \mathrm{~mm}$ 下 $100 \%, 3 \mathrm{~mm}$ 下 $90 \%$, $15 \mathrm{~mm}$ 下 $70 \%(3 \mathrm{~mm}$ 及 $15 \mathrm{~mm}$ 下の許容誤差士2\%)

(3) 水分 $14 \%$

(4) 爐空溫度 $1,050^{\circ} \sim 1,150^{\circ} \mathrm{C}$

（B）僓裂强度 潰裂强度とい5のは塊コークスを トラムに入れて回轉したときの破碎率てある。憒裂强 度試驗法は隼日本標隼規格になつている八幡式ドム 試驗法に據る。潰裂强度指數は $15 \mathrm{~mm}$ 網上の步留花 \%て表わした $15 \mathrm{~mm}$ 指數てめる。

上記の樣に潰裂强度と言えは普通 $15 \mathrm{~mm}$ 指數を表 わすのてあるが，大型高爐ては $25 \mathrm{~mm}$ 指數の方か爐

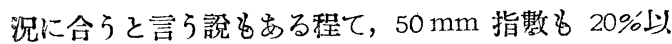
上を必要とするなととる言われている。

從つて最近は潰裂强度を見るとき $50 \mathrm{~mm}, 38 \mathrm{~mm}$, $25 \mathrm{~mm}, 15 \mathrm{~mm}$ の各指數の平均をして,この值を粒此 そ䊈してコークス强度を見る參考にしている。將來は

\section{第 3 表 手洗單味コークス清裂强度比較}

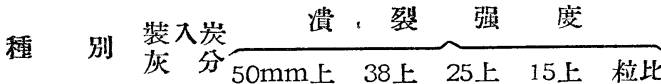
カナダ崖 $1153 \quad 45826823806288147072$ $\begin{array}{llllllll}\text { 米炭平均 } & 939 & 5561 & 7548 & 8660 & 9008 & 7694\end{array}$ 鹿町粉炭 $1394 \quad 58 \quad 16 \quad 8142 \quad 9086 \quad 9462 \quad 8127$ 開本特炭 $\quad 1398 \quad 3816 \quad 7685 \quad 87509382 \quad 7408$ 中央粉岩 $\quad \begin{array}{lllllll}1286 & 000 & 085 & 2449 & 70 & 14 & 2387\end{array}$

洼 昭和 $23,12,17$ 八幡製鐵所資钭厂輸入炎 (米 炭及カナタ岸) 飞就て」るり。
粒比の考えも規格に折迈む必要か起つて來るたろう。 第 3 表に粒比算定の一例を示す。

(C) 强度指數 製鐵用原料炭用効率の質的効率は 燒成コークスの强度によることにし，その强度は罐墝 試驗による僓裂强度に基礎を置く旨を迅へたが，その 使用價值を指數化するため, 潰裂强度と高爈の出銑能 率との關係を承めて，强度指數なるるのを導いた。

强度指數は强度指數圖表から求める。第 1 圖にその 圖表を示す。

第 1 圖强度指数圖表

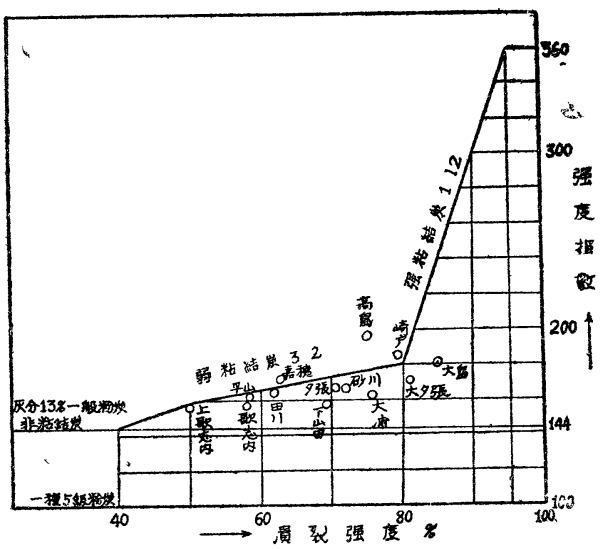

この圖表は次の棣にして作つた。

（1）非粘結炭及强粘結炭を一級炭の規格及價値指 數に從つて，一種五級粉炭の價值指數を 100 とし，そ の灰分が 13\% のときを144 とした。

（2）潰裂强度 $50 \%$ のときを160 とし，80\%のと きを 180 とした。

これは第 4 表々第 1 圖に示寸榬に，第二種原料㞸の 改正案指數に從い，各炭の序列を餘り亂さない㧼に考 慮したものてある。

\begin{tabular}{|c|c|c|c|c|c|c|c|c|}
\hline & & & 第 & 4 & 表 & & & \\
\hline 臵 & 唡 & 石炭灰分 & 潰裂品度 & 灰 分 & 級 & $\begin{array}{l}\text { 種崖 } \\
\text { 欧正案指數 }\end{array}$ & 灰 分 & $\begin{array}{l}\text { 灰分 } 13 \% \text { 時 } \\
\text { 價值指數 }\end{array}$ \\
\hline 大 & 島 & $\begin{array}{r}1313 \\
13\end{array}$ & 8496 & 1320 & 3 & 178 & 993 & 179 \\
\hline 大 & 夕 & 845 & 8091 & 103 & 2 & 187 & 905 & 170 \\
\hline 恰 & F & 1460 & 7976 & 1399 & 4 & 169 & 965 . & 175 \\
\hline 高島 双子 & 島 & 854 & 7500 & 99 & 1 & 196 & 100 & 196 \\
\hline 神 & 威 & 1483 & 7744 & 1280 & 3 & 178 & 993 & 177 \\
\hline 大 & 哺 & 1379 & 7566 & 1320 & 5 & 160 & 99.3 & 161 \\
\hline 砂 & 川 & 1289 & 7172 & 1260 & 4 & 169 & 986 & 166 \\
\hline 夕 & 張 & 720 & 7040 & 76 & 特3 & 205 & 81.1 & 166 \\
\hline 下 山 & 田 & 1477 & 6942 & 1240 & 5 & 160 & 985 & 158 \\
\hline
\end{tabular}




\begin{tabular}{|c|c|c|c|c|c|c|c|}
\hline 嘉 & 穗 & 17.43 & 62.73 & 17.00 & 6 & 148 & 86.0 \\
\hline 田 & 川 & 11.73 & 62.00 & 14.10 & 5 & 160 & 96.5 \\
\hline 平 & 山 & 14.34 & 58.63 & 13.50 & 5 & 160 & 98.25 \\
\hline 志 & 肉 & 11.41 & 58.38 & 12.70 & 4 & 169 & 99.0 \\
\hline 上 歌 志 & 内 & 11.48 & 50.43 & 12.60 & 5 & 160 & 98.6 \\
\hline
\end{tabular}

註 最後の 2 欄は灰分指數から計算したもの。表中の潰裂强度值々昭和 19 年 1 月の日鐵本社化工課「石 荞コーグス分析試驗表」から棌つた。夕張特粉は輪西の分であるが他は何れも八幡の分である。

潰裂强度 50〜80\% の傾斜をこの程度の緩さのま〉 に置いたのは次の考元萲にある。第 5 表の如くに强 粘結炭を配合して㙯成したュークスの謴裂强度は各元 の單味强度の比率より高い值に引揚げられる。そして その引揚率は强粘炭の配合割合が墰加するに從つて高 まり，45\%の时最高になる。そして闹こ〉に注意すべ き點は弱粘結洃の强度が低い時の方が高い時より引揚
率が大きいと言うことである。勿論序列が變る程では ないが，善が小さくなるのである。從つて强粘結炭を 多量に配合する高爐用コークスにあつては，出來上り のコークスの潰裂强魚には弱粘結炭の强度美の影響が 小さくつて來る。

依つて弱粘結炭の强度指數の傾科は緩になつて來 る。

第 5 表

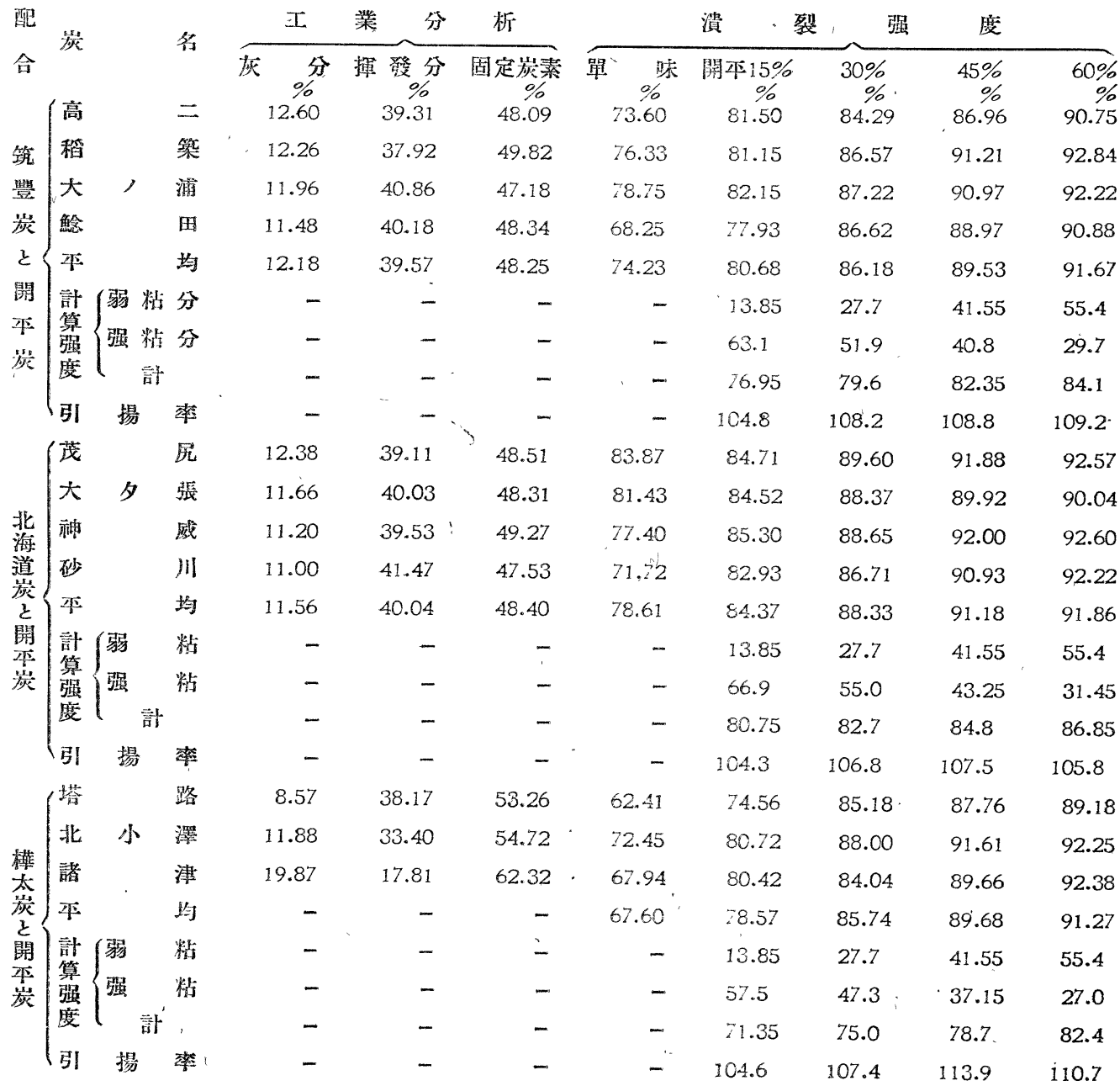

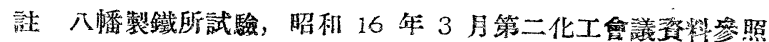


（3）潰裂强度 50 以下の場合でも 40 位までは低 灰分の石炭はュークス用に使われるので，40まで傾斜 をつけた。

（4）潰裂强度 80 で强粘結と弱粘結の境としたの ば第 2 圖に基く, 從來 85 以上を强粘結と稱していた のだが，低灰分のものは 85〜80 のものる小型高爐に は使われた。

\section{第 2 圆 コークス漬裂强度と臚高關係圖}

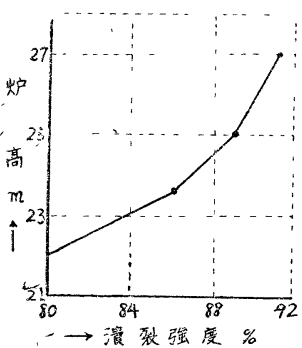

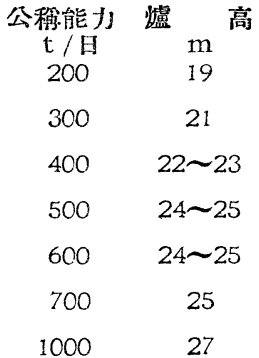

註 和田氏著「䁈際製鉄法」より，丸盖發行。

（5）潰裂强度 80９5 間の倾斜は次の考元に基い た。

（1）潰裂强度が 1 上れば愹鈸爐の出銑は 3 霄にな る。

これ经昭和 19 年 1 月 20 日八幡製鐵所長名で出され た「强粘結炭配合量低下に佐る銑鐵減韹見达」の書に 結論されている。

第 3 圖は同書記載のものである。又同圖は昭和 22 年 5,6 月號燃料協會誌に湯川氏に依つて紹介されている この結論には現在まで翼論はない由である。

\section{第 3 圖 コークス配合と潰裂强度及出銑効率}

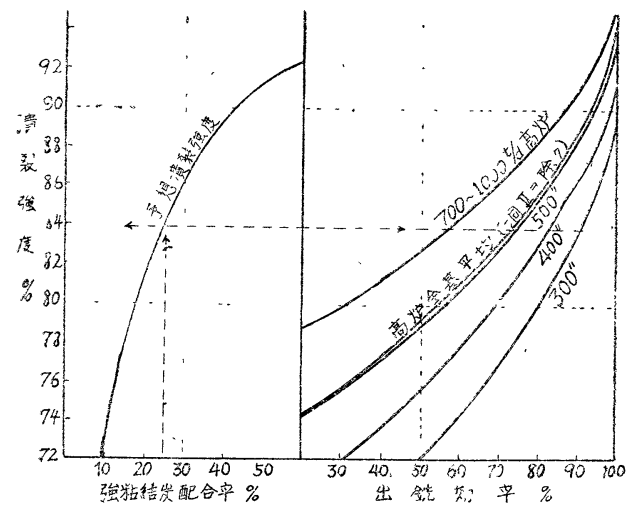

（口）（イ）の出銑增加分に對しては、・ークス比が 低下するからコークスの追加を要しない。

（八）銑鐵生產費は原料費80\%作業費20\%とする。

（＝）銑鐵生辇價格：石炭買上價格=3:1 と与る。
銑鐵は 3 號銑で置場渡價格は 12,580 圓である。石 炭價格は潰裂强度 $80 \%$ 强度指數 180 のものをとる。

以上の條件て潰裂强度 $1 \%$ 增に利盆を石炭量に換算 すると次の樣になる。

作業費節約量石炭換算

$$
3 \% \times 0.20=0.60 \% \quad 0.60 \% \times 3=1.8 \% \cdots \cdots \text {. (1) }
$$

コークス節約による石炭節約量

平均コークス比を 1.1 とし，裝入コークス步留を 63\%とする。

コークス節約量 $3 \% \times 1.1=3.3 \%$

石炭節約量 $3.3 \% \div 0.63=5.2 \% \cdots \cdots \ldots . . . . . . . .(2)$

(1) $+(2)=1.8 \%+5.2 \%=7 \%$

これは瀆裂强度 $80 \%$ 以上のコークスを高㠠に使用 する場合であつて,80\%以下のものには適用出來ない。 又現在の鋻型コークス爐では强度 80\% 以下のコー クスを造ることはコークス爐に破壤的損害を與える。

今浿裂强度 $80 \%$ の强度指嫩は 180 で，これを石炭 價格のベースにして以上の利盆計算をやつたから. 潰 裂强度 $80 \%$ 以上で $1 \%$ の變化は次の如き强度指數の 變化をるたらす。

$$
180 \times 0.07=12.6 \fallingdotseq 12
$$

この(4)の值は第 5 表の引揚率や第 3 圖に見る樣に潰裂 强度が 90\% を越えると，更に大さくなる筈だが，計 算を簡明にするため直線式にした。

(D) 强度指數圖表に用5る潰裂强度佔の是正 前述の樣に潰裂强度估は $15 \mathrm{~mm}$ 指數で單味罐燒試 驗を主體にするが，强粘結炭又は强粘結炭代用炭に對 しては弱粘結炭の配合罐燒試驗をやる，配合炭は二瀨 中央炭 (灰分 13\%) を標準炭として用い，その配合量 は70\%とする。

單味は粗炭の睢の灰分でやる。裝入時灰分でやるの が適嘗とも思われるが，粗炭で試驗されて不利のるの は適當な品位まで生崕者で調整せねばならぬ。配合は 装入時灰分で寸る。潰裂强度は單味より配合の方が高 く出るものるあるから，それらは配合强度の 1.05 倍 の值と單味の值と何れか高い方で探つて强度指數圖表 に用うる。

1.05 の係數は次の表を參考にして決めた。

第 6 表

荻種 手洗灰分 手淡嘿味 中央7 $0 \%$

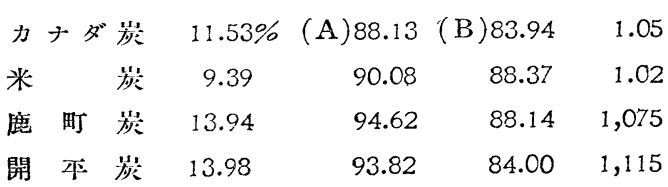


份潰裂强度 80 以上のるので $50 \mathrm{~mm}$ 指數が零のる のは强度指數圖表に對應させるときは 80 として用 5 る, 又單味溳裂强度が 84 以上で配合潰裂强度が 80 以 下゙のものは配合の方の估をとる, 後の 2 項のものは何 杞当高爐用コークスにならぬからかくしたのである。

\section{[N] 精度補正指數}

受入粗炭の中に $50 \mathrm{~mm}$ 以上の塊と $0.3 \mathrm{~mm}$ 以下の 徽粉が混在していると，色々取报上に困醮が件うので， 䞏の破碎費, 微粉の脫水費といら意味为ら控除指數を 惟つた。

$50 \mathrm{~mm}$ 以上塊笼混入量 $1 \%$ につき 0.5

$0.3 \mathrm{~mm}$ 以下微粉炭混入量 $15 \%$ を越える $1 \%$ につき 0.5

指軗 100 を 2,000 圆と寸ると 0.5 は 10 圓に當る。郎 亏 $100 \mathrm{~kg}$ につき 10 圓といらことになる。

\section{[V] 酼籍䋠正诣數}

硫带は出銑能率を低下させると共に敛鐵品位を下げ ろから控除指數を設けた。

ソ聯の「治金の理論と賽際」誌 1940 年 4 號にはコ ークスの中の Sが $0.1 \%$ 增せば出銑量ぶ $1.2 \%$ 減ずる 之言5例も出されているが，日本ではま炕確定した資

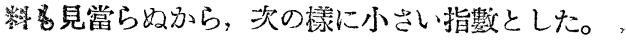

裝入時灰分の㭙の全硫黄量 $0.7 \%$ を越ゆる $0.1 \%$ につき 1

$0.7 \%$ を境としたのは從來の製鐵用原料炭中の含有量 はこの程度であつたからである。

裝入時灰分の時としたのは洗炭によつて2〜15\%の Sガ除去出來るからである。それは大體ボタ部分に 含有量が多いからである。

石策中のSはその $70 \%$ 前後のものがコークス中に移 行寺るが，石炭中の含有率の 99〜90\% に當るものが コークス中含有率になることになる。昭和 22 年 2 月 25 日〜 4 月 10 日の八幡製鐵所試驗の「脫硫研究會二 一タス關係報告書」を見ると第 乙表の禁な例がある。

\section{第 7 表}

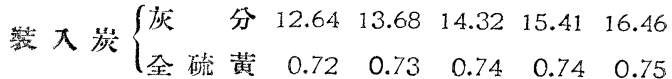

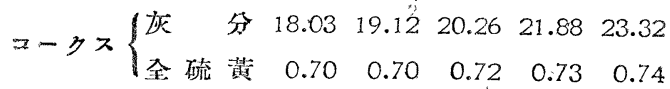

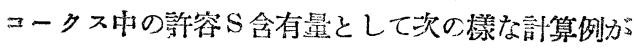
嵌る。

銑鐵中のS $\mathrm{S}$ - $05 \%$ 以下 ( 1 號銑規格)

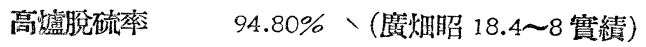
装入原料中S： $0.20 \%$

鉄 $\mathrm{t}$ 當原料使用量 $1.75 \mathrm{t}$
銑 $\mathrm{t}$ 當コークス所要量 $1.1 \mathrm{t}$

銑鐵 $\mathrm{t}$ 當裝入物に許容される $\mathrm{S}$ 量

$$
=0.5 \mathrm{~kg} \div \frac{100-94.8}{100} \doteqdot 9.8 \mathrm{~kg}
$$

装入原料中の $\mathrm{S}$ 量 $=2 \mathrm{~kg} \times 1.75=3.5 \mathrm{~kg}$

コークス中の許容 $\mathrm{S}$ 量 $=9.8 \mathrm{~kg}-3.5 \mathrm{~kg}=6.3 \mathrm{~kg}$

コークス中許容 $\mathrm{S}$ 含有率

$$
=\frac{6.3}{1,000} \div 1.1 \times 1 \mathrm{CO}=0.573 \% \text { 以下 }
$$

昭和 18 年の廣畑製鐵那でュークス中 $\mathrm{S}=0.69 \%$

現在の八幡製鐵所で $0.8 \%$ 位, 装入原料中 $\mathrm{S}=0.3 \%$ 位 2 號銑の $\mathrm{S}$ 規格は $0.08 \%$ 以下， 3 號銑は $0.1 \%$ 以下

\section{[V] 賈值指 數}

價值指數は灰分指數 (量的效率) そ强度指數（質的 效率)の相乘積となる。

價值指數 $=$ 灰分指数 $\times$ 强度指數

$$
\div \text { ( 粒度補正指數十硫黄補正指數) }
$$

徙 小數點は 4 捨 5 入

\section{[VII] 瑻值指數算定方法要約}

\section{[I $]$ [VI]要約すると次の栐になる。}

\section{A 灰分指数}

第 1 表から算出した標準灰分 $13 \%$ の換算總步留を 灰分指數とする。

表中洗炭步留は次式から求める。

實際洗炭步留 =可洗曲線から求めた灰分の步留一 $\mathrm{A}$

A ……3\% 可洗曲線步留(裝入時灰分) $90 \%$ 以上

$\begin{array}{lll}5 \% & \text { " } & 70 \sim 89 \% \\ 7 \% & 69 \% \text { 以下 }\end{array}$

B 强度指數

1. 湦裂强度

䚭燒試驗 翼味潰裂强度……………….... $\%$

二観中央炭 $7 \mathrm{C} \%$ 配合潰裂强度 $\times 1.05 \cdots \mathrm{b} \%$

（1） a, b の队大犬き方を探る。但し單味潰裂强

度 $84 \%$ 以上で配合が $80 \%$ 以下の場合は bの 方を探る。

（ロ）單味探用の場合でる配合袜用の場合でも潰 裂强度が 80 以上の場合に，潰裂强度 $50 \mathrm{~mm}$ 指數が零のときは，その潰裂强度は 80 として 用いる。

2. 强庋指數

强度指數圖表 (第 1 圖) 加潰裂强度に對應于る 强度指數を求める。

C 粒度補正指㜢

$50 \mathrm{~mm}$ 以上の塊炭混入量 $1 \%$ につき 0.5

$0.3 \mathrm{~mm}$ 以下の微㸮炭混入量 $15 \%$ を越ゆる $1 \%$ 
につき 0.5

D 硫異補正指數

装入時灰分の時の全政黄量 $0.7 \%$ を越ゆる $0.1 \%$ に つき 1 .

\section{E 一價值指數}

價值指數 $=$ 灰分指數 $\times$ 强度指數 $-($ 粒度補正指數 + 硫黄補正指數) 小數點は 4 捨 5 入
附 記

他の規格炭の價値指數算出法との振合上算出方法芫

更に簡明にする必要がある場合は，灰分指數中の二: 號炭補正量之粒度補正指數並びに硫黃補正指數を省 略することは考え得る。

\begin{tabular}{|c|c|c|c|c|c|c|c|c|c|}
\hline & & & & 第 & 8 & 表 可洗性 & 旨數 & & \\
\hline 炭 & 種 & 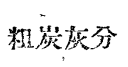 & 装入時灰分 & 沙炭步留 & 麻分差 & 灰分梢正量 & 二號焱步留 & 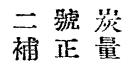 & 總步留 \\
\hline カナ ダ & 炭 & 13 & 13 & 1.00 & 0 & 0 & 0 & 0 & 1.00 \\
\hline 米 & 炭 & 8 & 8 & 1.00 & +5 & +0.775 & 0 & 0 & 1.175 \\
\hline 本 & 炭 & 19.52 & 13 & 0.86 & 0 & 0 & 8 & 2.7 & 0.887 \\
\hline 磨 町 & 炭 & 25 & 16 & 0.70 & -3 & -0.105 & 12 & 4 & 0.635 \\
\hline 二 瀨 中 央 & 炭 & 18 & 13 & 0.88 & 0 & 0 & 3 & 1 & 0.87 \\
\hline 高 島 双 & 子 & 9.9 & 9.9 & 1.00 & +3.1 & +0.109 & 0 & 0 & $1.10 y$ \\
\hline 北松一級 & 炭 & 16 & 13 & 0.90 & 0 & 0 & 6 & 2 & 0.920 \\
\hline 夕 & 張 & 7.60 & 7.6 & 1.00 & +5.4 & +0.189 & 0 & 0 & 1.189 \\
\hline 大 & 張 & 10.3 & 10.3 & 1.00 & +2.7 & +0.095 & 0 & 0 & 1.095 \\
\hline
\end{tabular}

\section{筫 9 表 價愠指數}

\begin{tabular}{|c|c|c|c|c|c|c|c|c|}
\hline 炭 & 種 & 謴裂强度 & 强度指數 & 可洗性指數 & $\begin{array}{l}\text { 粒 应 } \\
\text { 補正指數 }\end{array}$ & $\begin{array}{l}\text { 硫 黃 } \\
\text { 補正指數 }\end{array}$ & 價値指數 & $\begin{array}{l}\text { 改案二種 } \\
\text { 價值指數 }\end{array}$ \\
\hline カ ナ ダ & 炭 & 88.5 & 282 & 1.00 & 2.5 & 0 & 280 & - \\
\hline 米 & 炭 & 92.5 & 330 & 1.175 & 2.0 & 1.5 & 384 & - \\
\hline 平 & 炭 & 93.8 & 345.6 & 0.887 & 0 & 4 & 303 & - \\
\hline 町 & 炭 & : 94.5 & 354 & 0.635 & 0 & 0 & 225 & (146) \\
\hline 央 & 炭 & 70 & 173.3 & 0.87 & 0 & 0 & 151 & 136 \\
\hline 高 島 双 & $子$ & 75 & 176.7 & 1.109 & 0 & 0 & 196 & 205 \\
\hline 北松一級 & 炭 & 94.5 & 354 & 0.920 & 0 & 0 & 325 & (176) \\
\hline 夕 & 張 & 70.4 & 174 & 1.189 & 0 & 0 & 207 & 205 \\
\hline 夕 & 張 & $80.9 \rightarrow 80$ & 180 & 1.095 & 0 & 0 & 197 & 187 \\
\hline
\end{tabular}

\section{檜油の接觸分解に關する研究 第 $3 \sim 5$ 報}

一一昭和 22 年 12 月 6 日受瑅——

名占屋大學工學部應用化學敎窒 恩 田 格 三 郎

\section{[I] 絠 , 言}

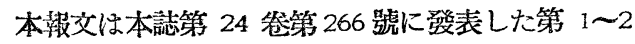
報の續報であるが，談研究がテルペン類より高オクタ ン價燃料の製造を目的として行つたのに對して，本㗇

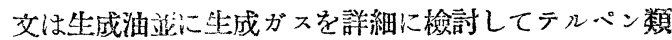
の接觸分解機權に關し考察を行つたるのである。何試 料分解裝置，分此方法等は前報告と同樣である。

[II]第了報活降白土によ西婹觸分解 